\title{
The Platform Business Model Canvas a Proposition in a Design Science Approach
}

\author{
Davis Eisape \\ Chair for Innovation Economics, Institute for Technology and Management, Faculty of Economics and Management, Technical University of \\ Berlin (TU Berlin), Berlin, Germany
}

Email address:

Davis.eisape@outlook.de

\section{To cite this article:}

Davis Eisape. The Platform Business Model Canvas a Proposition in a Design Science Approach. American Journal of Management Science and Engineering. Vol. 4, No. 6, 2019, pp. 91-107. doi: 10.11648/j.ajmse.20190406.12

Received: November 7, 2019; Accepted: December 16, 2019; Published: December 24, 2019

\begin{abstract}
Literature research has shown that there is no proven business model canvas for platforms. Such a canvas would be a vital tool that provides added value to companies and innovators for various purposes: sharing, communication (internal and external), description, analysis, management, planning and partnering. In addition, a platform business model canvas helps follow a systematic but also pragmatic approach with regards to the transformation of a pipeline business to a platform business, the task to design a new platform or to describe an existing platform business model. The goal of this research is therefore to create a platform business model canvas that is easy to use and helps capture platform business models in a comprehensive and effective way following the Design Science Approach. The basic components/building blocks and the necessary perspectives for the platform business model canvas, are derived from literature. The need for three or more perspectives, is furtherly discussed on basis of Osterwalder's business model canvas by outsourcing dimensions of control. Components and perspectives are subsequently verified through a qualitative analysis of the about-us-pages of 32 platform websites. The components/building blocks and perspectives are then put together to form a platform business model canvas, which is then evaluated through an illustrative case study explaining the platform business model of eBay.
\end{abstract}

Keywords: Platform Business Model Canvas, Platform Economy, Business Model Canvas, Design Science Approach, eBay Case Study

\section{Introduction}

\subsection{Objective and Relevance of This Research}

Literature research has shown that there is no proven business model canvas for platforms. Such a canvas would be a tool that provides added value to companies and innovators for various purposes: sharing, communication (internal and external), description, analysis, management, planning and partnering. Kindström emphasizes that a business model approach to researching a particular organization provides a useful analytical framework for understanding the organization and its inherent components [1]. In addition, a platform business model canvas helps follow a systematic but also pragmatic approach with regards to the transformation of a pipeline business to a platform business, the task to design a new platform or to describe an existing platform business model.
The central research question based on the literature review and a theoretical derivation is: How is a platform business model canvas structured?

\subsection{Method of the Research}

March \& Smith presented design science as a scientific category to find solutions to real-world problems [2-5]. The question whether the solution orientation of this paper is sufficient for a scientific work is answered by the methodological context put forward by Hevner et al, as Wieringa summarizes: (1) business needs motivate the development of validated artifacts that meet those needs, and [...] (2) the development of justified theories about these artifacts produces knowledge that can be added to the shared knowledge base of design scientists [3].

Therefore, the platform business model research in this paper is based on the design science framework described above and covers the research activities Build and Evaluate 
and has the research output of Constructs, Models and Instantiations. As already mentioned, the main research objective of this paper is to find a model that enables the conceptual and structured representation of a firm's platform business logic as an easy to use practical tool. Therefore, Build and Evaluate will be of central significance, whereas Instantiation will apply the model to a platform business application via a case study that will simultaneously evaluate the model's adequacy. The research activities theorize and justify as well as the research output Method are not part of this research (see table 1).

Table 1. Design Science Framework and methods used in this paper adapted from [8].

\begin{tabular}{|c|c|c|c|c|c|}
\hline & \multicolumn{5}{|c|}{ Research output } \\
\hline & & Constructs & Model & Method & Instantiation \\
\hline \multirow{4}{*}{$\begin{array}{l}\text { Research } \\
\text { activities }\end{array}$} & Build & $\begin{array}{l}\text { What are the building blocks or components } \\
\text { of a business model canvas for platforms and } \\
\text { how would they be defined? }\end{array}$ & $\begin{array}{l}\text { Define a model that will enable } \\
\text { firms to express and create } \\
\text { their platform business model }\end{array}$ & - & $\begin{array}{l}\text { Create a Platform Business } \\
\text { Model Canvas Prototype }\end{array}$ \\
\hline & Evaluate & $\begin{array}{l}\text { Compare model with literature Test the } \\
\text { adequacy and dissemination of the defined } \\
\text { constructs }\end{array}$ & $\begin{array}{l}\text { Test the model's adequacy } \\
\text { against reality }\end{array}$ & - & $\begin{array}{l}\text { Apply the model to } \\
\text { platform business } \\
\text { applications }\end{array}$ \\
\hline & Theorize & - & - & - & - \\
\hline & Justify & - & - & - & - \\
\hline
\end{tabular}

\section{Platforms}

The terminus "platform" has become quite ubiquitous, appearing in the fields of new product development and operations management $[9,10]$, technology strategy [11-13] and in industrial economics [14, 15]. Literature basically distinguishes between two perspectives: the engineerscientific perspective on platforms as modular technological architectures and an economic perspective on platforms as markets [16].

Regardless of the platform perspective, platform operators need to develop a successful platform strategy and a platform business model. They need an understanding what needs and expectations all stakeholders of a platform have and effectively match them. Here they differ significantly from traditional pipeline business models. Compared to value creation in linear value chains, the complexity of value creation in an innovation ecosystem increases, because it depends on the success of several actors. Value creation in this context means the totality of collaborative processes and/or activities that create value for stakeholders and customers [17]. A holistic perspective is needed to minimize innovation challenges in the entire platform ecosystem and maximize value creation in the innovation platform $[18,19]$.

Platform providers need to master four dimensions to successfully establish and orchestrate an innovation or transaction platform and ensure their own share of value. This includes stimulating the creation of value in the platform, protecting the values created in the platform, further developing the platform (material work) and gaining value for oneself from the platform. These are the core elements of every platform business model [18, 20, 21].
To achieve the objectives within this research framework very different methodologies are necessary. In analogy to Palvia et al. [6, 7] the methods speculation/commentary, frameworks and conceptual models, library research, literature analysis research, (illustrative) case study, interview and secondary data [8] are used in this research. furthermore, the library research is supplemented by an Internet search and, the qualitative web content analysis is used to test the adequacy and dissemination of the defined constructs that make up a platform.

\section{Business Models}

\subsection{Osterwalder's Business Model Canvas}

Speaking in rather general terms, a business model can be defined as a management hypothesis about what customers want, how they want it and how the company can organize itself to best meet those needs, get paid for it and make a profit [22-25]. A business model consists of various components or building blocks [8] that have been designed at different levels of aggregation.

The business model canvas of Osterwalder shows the central building blocks of a business model with regards to the infrastructure of value creation, the benefits and value propositions and the revenue model, the addressed costumers and the infrastructure to address costumers. The nine individual building blocks stand in a very specific relationship to each other. At the heart of the business model are the value propositions of the products and services that are to be successfully offered to customers. Here it is listed which value propositions the offers have and which customer benefits they fulfil.

The value proposition then basically divides the entire business model into two perspectives - business external and internal [26]. The rather externally visible right-hand side describes how the value proposition reaches the customer and how revenues are generated. In the Customer Segments area, the different customer groups that an organization serves are listed. These customers are usually addressed via different channels. Customer Relationships describe how the relationship with customers is maintained. Finally, revenue streams show the sources of revenue and represent the total result of successfully offered products and services. On the rather internal left side we find all the elements of the value 
chain that lead to the creation of the value proposition and create costs. Key Partnerships are either partners to whom key activities or resources are outsourced to or stakeholders who support the project in one or more areas. Finally, the cost structure adds up all expenses of the value chain [27].

With the business model canvas as a tool, business models can easily be visualized and created by individuals and by groups. In addition, the business model canvas also serves as a somewhat standardized communication format for business models that already exist at the market [27].

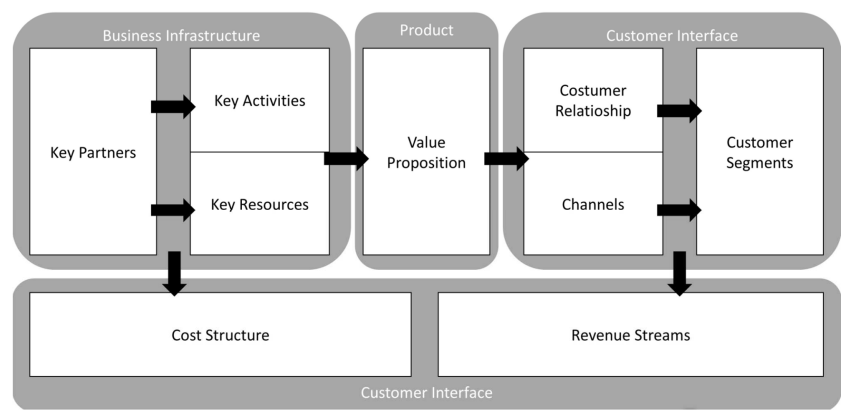

Figure 1. Visual representation according to the "business model canvas" adapted from Osterwalder [27, 28].

\subsection{The (Platform) Business Model Definition}

To identify a definition that would be fitting for this paper's scope with regard to platform business models a collection of 43 business model definitions [23, 27, 29-46] was analyzed.

This research will introduce a new rather specific definition that combines these definitions to specifically match platforms, without excluding other forms of business models. A business model is therefore defined as

the description of the roles of the company, its customers, allies and suppliers, the interrelations between the actors, the transactions of products, services, know-how, information and value and the alignment of the value creation potentials and advantages for the different players.

\section{Components for a Platform Business Model Canvas}

Taking literature and existing platform business model canvas in account ([47-52], compare [53, 54]) (see table 2), the platform business model canvas that this research is aiming to create will consist of the following building blocks.

Core Value Unit: This is the center piece of every platform. It describes the smallest unit that is created and consumed. It is the connection point between all stakeholders of a platform.

Job, pain, gain: Every player that decides to join a platform has the goal to solve a problem or to satisfy an own need. Therefore, for a platform owner to be able to match interests he or she must understand how a solution made on the platform by one platform user can be newer, better, more up to date, cheaper, easier or more user-friendly with respect to the needs and problems of another platform user.
Key Activities: Participating on a platform means to be active. The key activities of every participant that are necessary to keep the platform working, must be portrayed to understand how stakeholders can be stimulated to be active.

Key Resources: In a platform eco system every participant that is active has some sort of costs related to these activities. Running, Contributing, Providing, or Consuming over a platform always needs some sort of resources involved. From time, to internet connectivity, to money, goods, know how, technology, etc. various resourceful activities by the various stakeholders need to be understood as e. g. it may be the goal to keep the platform entry as low-barrier as possible. Therefore, it is necessary to understand, what are the most important expenses for each player without which the platform business model would not work.

Channels: Potential participants can only participate in something they know about and where they have access to. Understanding through what channels stakeholders can be addressed is key to have a working platform.

Revenue Streams: There are often several ways to capture value. The platform owner as well as the other active platform stakeholders participate to gain some sort of value. This can be money, merit, fame, know-how, resources, etc. that result from successful transactions.

Cost Structure: Looking at the cost structure in context of a platform business model it becomes clear that platform participants basically have two types of costs, the key resources needed to participate on a platform (as mentioned above) and costs related to successful transaction between platform participants. Therefore, to reduce complexity, hereinafter cost structure and revenue will be subsumed to transactions that are always to be understood as bi-directional, representing cost and revenue.

Transaction: Transactions are the result of complementarily corresponding interests, where two needs are met through the exchange of goods, services, information or money. Therefore, it is key to understand what can be transacted and how each platform-user can benefit from transactions.

Key Partnerships: Platform owners often need technology, know-how, processes or resources of key partners to generate value on the platform. Apart from facilitating activities or increasing the effectiveness of the platform it can also help to spread risks across several shoulders.

Customer: Depending on the platform they can be called Users, Buyers, Consumers, etc. Although a platform does not specifically aim at customers in the real sense of the word, as it does not sell something to a specific group of people, a platform must understand how participants can be customers to suppliers that offer products, services or information on the platform. Therefore, while designing or portraying a platform the often-interchangeable role of consumers and providers needs to be understood.

Owner: The platform owner has a unique perspective, as owner's interests are the brackets around the activities on the platform. Laying out the owner's perspective is vital to have a holistic understanding of a platforms functionalities. 
Contributor: Depending on the platform they can be called Contributors, Suppliers, Sellers, Providers, etc. Participants that offer something on a platform are vital for possible transactions and therefore need a dedicated perspective, to be understood.

Filters: A vital tool to keep platforms healthy and working are filters that make sure that the right people get access to the platform. This not to be mistaken for search filters that participants use to find other participants on the platform.
Filters allow for a barrier-regulation, to coordinate who gets access to a platform and who doesn't. Their coordinated absence make sense in a no-barrier driven approach, whereas their presence make sense in a curated approach.

Governance: Every platform needs some rules to promote and ensure a healthy environment, where innovation and transactions can thrive. Protecting value as well as stimulating value creation are key elements that require governance.

Table 2. Building Blocks for a Platform Business Model Canvas derived from literature.

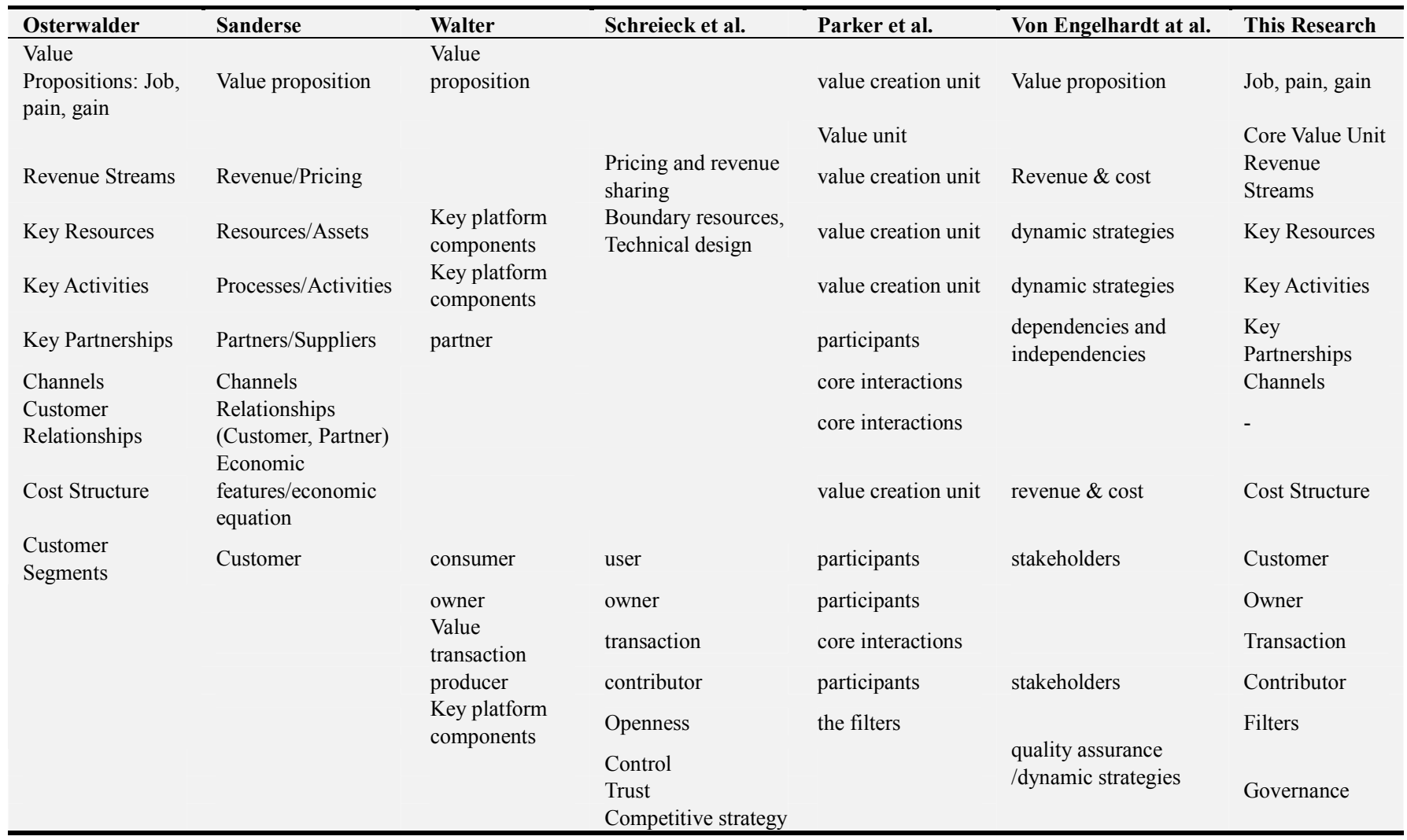

\section{Outsourcing Dimensions of Control}

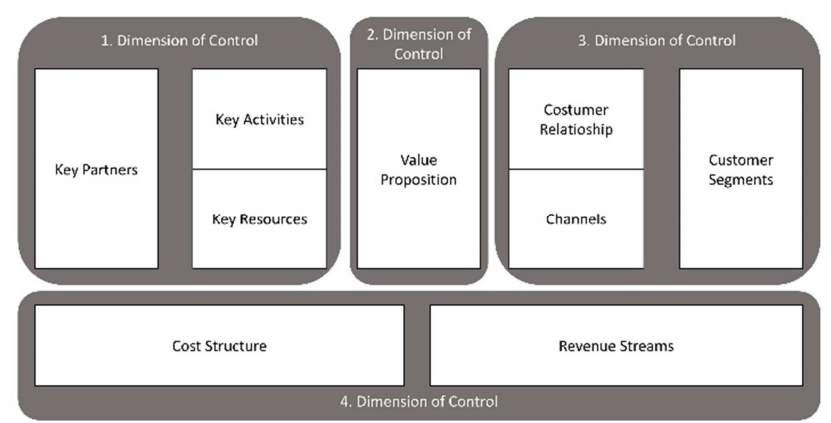

Figure 2. Four Dimensions of Control in a Business Model adapted from Osterwalder [8].

This chapter will discuss the "four dimensions of control" which directly correspond to Osterwalder's four principal areas, which are value proposition (the product/service), the infrastructure (activities, resources and partners), the customers (relationship, channels and customer segments), and the revenue model (cost structure and revenue streams).

The first dimension of outsourced control will be to place the handling of key infrastructure into the hands of external partners. In this case, a business stands before the challenge to induce key partners to offer key product parts, processes, resources, technologies, know-how and activities to its business activities.

Therefore, a firm must truly understand the business model of its key ally/partner in order to create a business opportunity for them that in return helps its own business purpose [55].

The second dimension of outsourced control will be to place the production of goods or the provision of services into external hands, which transforms a business from a producer or service provider to the business model of a publisher [56].

The third dimension of outsourced control would be to 
invert control and pass it to the customers. This means that the control over the entire area of customer approach and customer management is outsourced, so that the "control" or better the creative initiative lies with the customers. This phenomenon is known as crowdsourcing [57].

The fourth dimension of outsourced control is when organizations or individuals use resources to create products or provide services but don't pay for the costs and don't capture value. The creative commons approach to copyright may be a concept that applies here [58].

Simultaneously outsourcing the first and second dimension of control creates a business model, where customer relationship and capturing value is in the center of internal activities which ought to be aligned with an external product and service creation and external resources. This perfectly describes the business model of sales agents/broker [59].

A platform in some extend is the combination of a strategic alliance, with publishing activities, where products are created by a crowd of innovators that sometimes may be open source but always have inherent the ability to match interests of demand and supply like a broker.

The business model canvas therefore cannot consist of principal areas that lay within the activity radius of a firm but needs to facilitate the understanding and alignment of these external value propositions and external activities.

\section{Evaluation of Components/Building Blocks}

\subsection{Evaluation Method: The Deductive Qualitative Content Analysis}

Having derived the building blocks from literature the key question is, if these represent the real world, which is in accordance to the design science framework of March and Smith. To evaluate the building blocks a qualitative content analysis of website-description-text according to Mayring is employed [60].

The focus of the evaluation is on the public content on the "About Us"-pages of 32 platform websites. The goal is to structure these texts according to a pre-defined coding guide (see table 3 ) that consists of the category definitions, coding examples and coding rules, thus following a deductive category application [60]. The buildings blocks are the coding categories that are used to search for evidence for each category using a software called QDA Miner Lite [61]. Subsequently the results are interpreted and discussed.

In addition to the components two further categories help to indicate that the websites truly describe platforms. These additional indicators are "labeling as a platform or network", by using the words "platform", "network" or "eco-system" compare [62] and "high number of members" [49].

Table 3. Coding guide for finding evidence of platform components on platform websites.

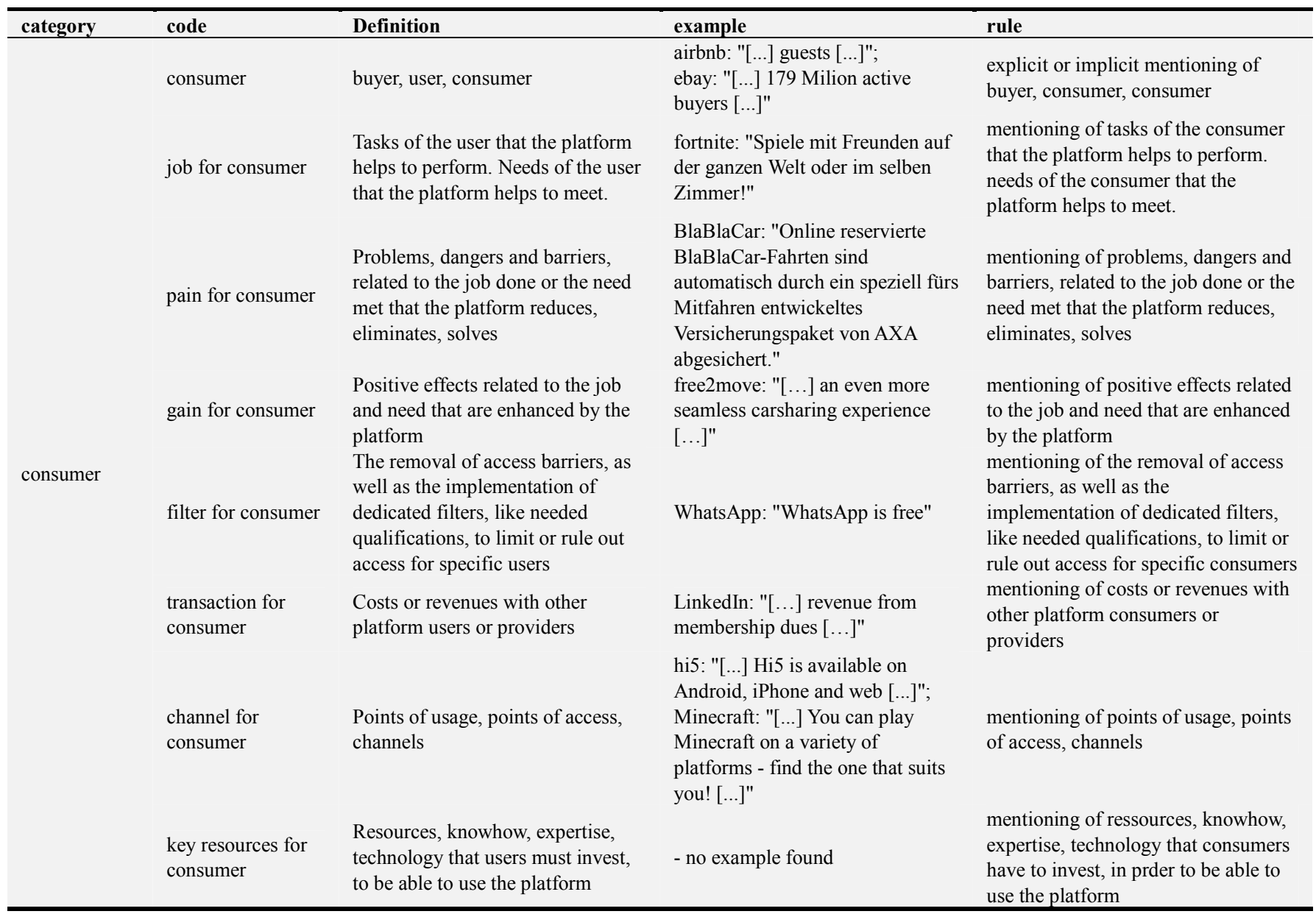




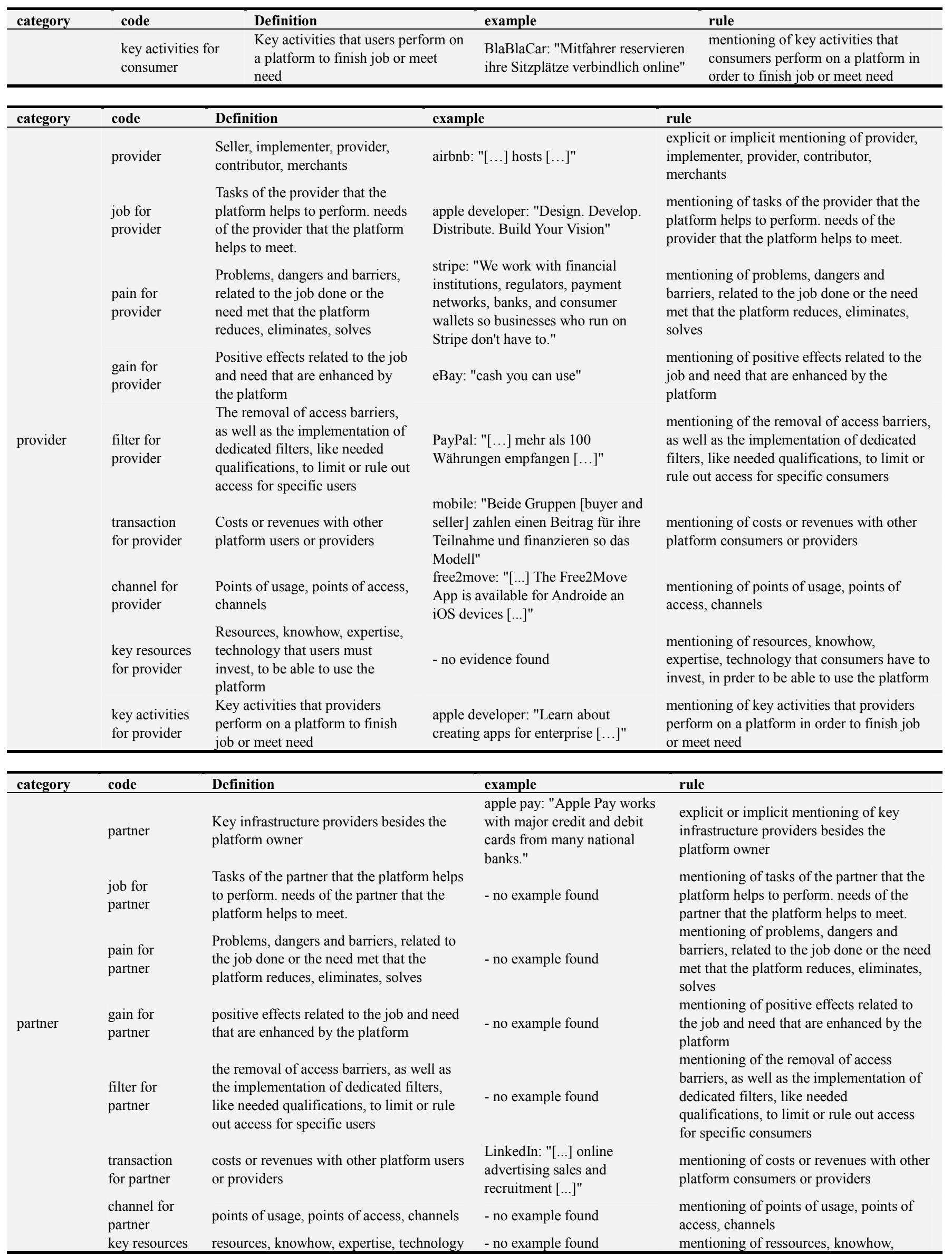




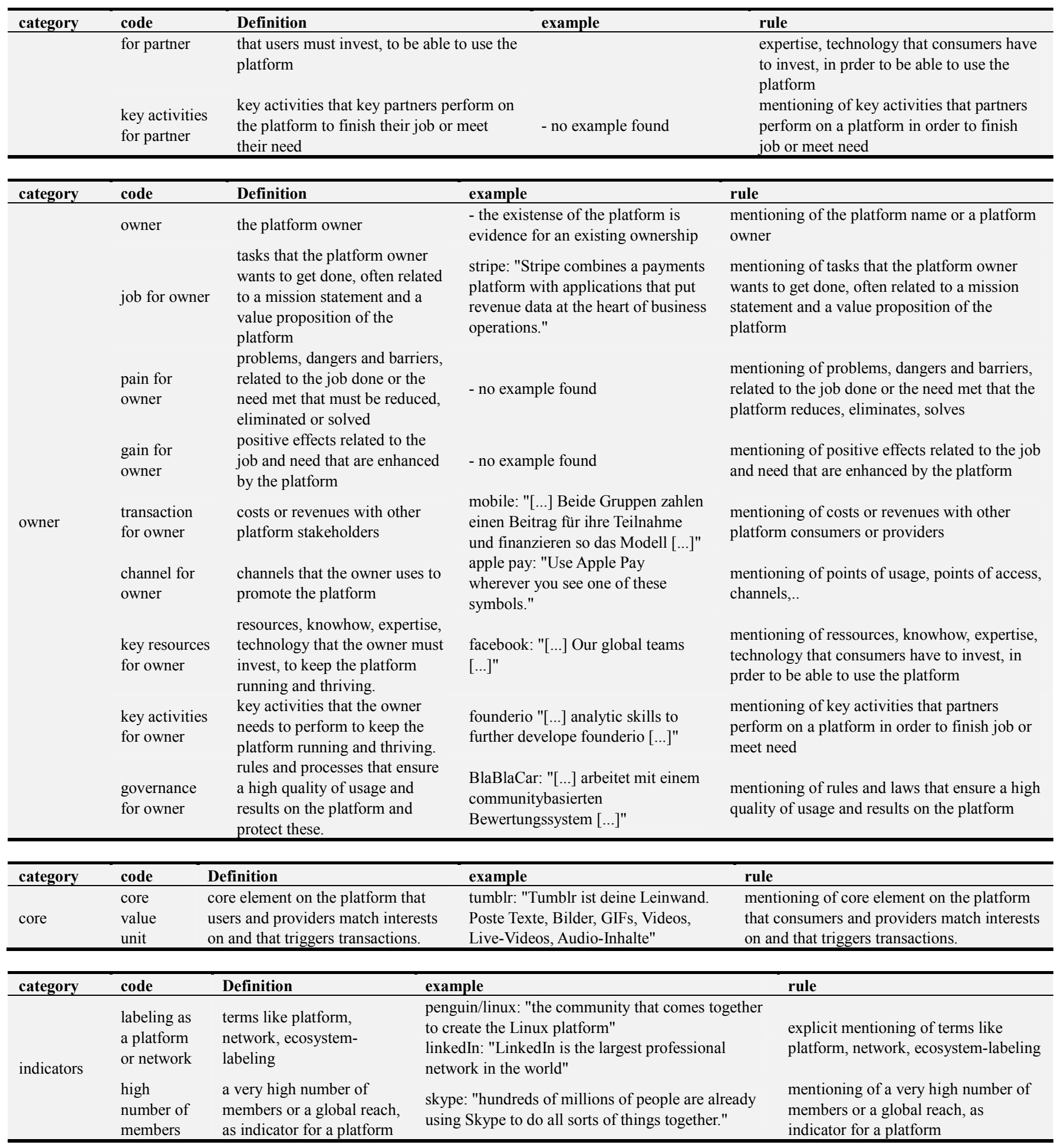

\subsection{Platform Types and Sample Platforms}

Moazed, the author of the book "Modern Monopolies" states on his website that there are nine types of platform businesses regarding the value that they exchange: service platform, product platform, payment platform, investment platform, social platform, communication platform, social gaming platform, content platform, development platform [63].

Mobility platforms could be categorized as service platforms, but as they mainly integrate corporate mobility providers for a superior user experience [64], they do differ from service platforms, where often private people offer services to other private users, like Uber, Airbnb, etc. From the perspective of the value that is exchanged a service platform usually offers one service from one provider to one or more users at a time (1:1 or 1:n), whereas mobility platforms combine many services of service providers in a travel chain to achieve one integrated user-experience (n:1 or $\mathrm{n}: \mathrm{n})$, which is unique compared to a general service platform. 
Therefore, this research defines ten types of platforms.

For this research between two and four platforms for each platform type are analyzed. Airbnb, Uber and BlaBlaCar are service platforms, as they allow providers to privately offer a service to users. Moovel/ReachNow, free2move and Ridecell are mobility platforms that allow mainly corporate providers to offer mobility-as-a-service to users. eBay, Mobile. de and eBay Kleinanzeigen are product platforms that allow providers to sell tangible products to users. PayPal, Stripe and Amazon Pay are payment platforms that help implementers to offer users an effortless way to pay online. Angellist, Founderio and Companisto are investment platforms that help to bring people seeking investors or partners together with potential prospects. Facebook, twitter, hi5 and LinkedIn are social platforms that allow users to connect online. WhatsApp and Skype are communication platforms that allow users to communicate online. Fortnite, Minecraft and snap games are social gaming platforms that enable users to connect and play games online together. YouTube, Vimeo, Tumblr and Instagram are content platforms that allow providers to share media content and users to view these. Linux, apple developer and android developers are development platforms that allow contributors to create, modify and spread software applications (see table 4).

This collection of platforms is a mix of very successful and known platforms (e.g. Facebook, YouTube, Uber) compare [65] as well as rather nationally known smaller platforms (e.g. Founderio, BlaBlaCar, mobile.de). The variety in types and 'success' is important to have a representative sample.

Table 4. Platforms, platform type, core value unit and their 'About us' pages used for this research.

\begin{tabular}{|c|c|c|c|}
\hline platform type & core value unit & platform name & web adress (visited on 29.6.2019) \\
\hline & service offers like & airbnb & https://press.airbnb.com/de/about-us/ \\
\hline service platform & accommodations $/ \mathrm{r}$ & uber & https://www.uber.com/en-DE/about/ \\
\hline & ides & BlaBla Car & https://blog.BlaBlaCar.de/about-us \\
\hline mobility platform & $\begin{array}{l}\text { combination of } \\
\text { mode of travelling }\end{array}$ & $\begin{array}{l}\text { moovel/reachnow } \\
\text { free } 2 \text { move } \\
\text { ridecell }\end{array}$ & $\begin{array}{l}\text { https://www.moovel.com/de } \\
\text { https://de.free2move.com/en/about } \\
\text { https://ridecell.com/de/about/ }\end{array}$ \\
\hline product platform & $\begin{array}{l}\text { product } \\
\text { description }\end{array}$ & $\begin{array}{l}\text { ebay } \\
\text { mobile.de } \\
\text { ebay kleinanzeigen } \\
\text { paypal }\end{array}$ & $\begin{array}{l}\text { https://www.ebayinc.com/our-company/who-we-are/ } \\
\text { https://cms.mobile.de/de/unternehmen/kurzportrait.html } \\
\text { https://themen.ebay-kleinanzeigen.de/ueber-uns/ } \\
\text { https://www.paypal.com/de/webapps/mpp/about }\end{array}$ \\
\hline payment platform & transaction option & $\begin{array}{l}\text { Stripe } \\
\text { amazon pay }\end{array}$ & $\begin{array}{l}\text { https://stripe.com/about } \\
\text { https://pay.amazon.com/us }\end{array}$ \\
\hline $\begin{array}{l}\text { investment } \\
\text { platform }\end{array}$ & $\begin{array}{l}\text { business } \\
\text { description }\end{array}$ & $\begin{array}{l}\text { angellist } \\
\text { founderio } \\
\text { Companisto }\end{array}$ & $\begin{array}{l}\text { https://angel.co/angellist/jobs } \\
\text { https://www.founderio.com/de/ueberuns } \\
\text { https://www.companisto.com/en/about }\end{array}$ \\
\hline $\begin{array}{l}\text { communication } \\
\text { platform }\end{array}$ & message & $\begin{array}{l}\text { whatsapp } \\
\text { skype }\end{array}$ & $\begin{array}{l}\text { https://www.whatsapp.com/about/ } \\
\text { https://support.skype.com/en/faq/FA6/what-is-skype }\end{array}$ \\
\hline $\begin{array}{l}\text { social gaming } \\
\text { platform }\end{array}$ & $\begin{array}{l}\text { Status update on } \\
\text { game session }\end{array}$ & $\begin{array}{l}\text { fortnite } \\
\text { minecraft } \\
\text { snap games }\end{array}$ & $\begin{array}{l}\text { The Prospector, April 17, } 2018 \\
\text { https://www.minecraft.net/en-us/what-is-minecraft/ } \\
\text { https://www.snap.com/en-US/news/post/snap-partner-summit-introducing-snap-games/ }\end{array}$ \\
\hline content platform & $\begin{array}{l}\text { video, pictures, } \\
\text { text }\end{array}$ & $\begin{array}{l}\text { youtube } \\
\text { vimeo } \\
\text { instagram } \\
\text { tumblr }\end{array}$ & $\begin{array}{l}\text { https://vimeo.com/about } \\
\text { https://www.instagram.com/about/us/ } \\
\text { https://www.tumblr.com/about }\end{array}$ \\
\hline $\begin{array}{l}\text { development } \\
\text { platform }\end{array}$ & $\begin{array}{l}\text { code, software or } \\
\text { apps update }\end{array}$ & $\begin{array}{l}\text { linux } \\
\text { apple developer } \\
\text { android developer }\end{array}$ & $\begin{array}{l}\text { https://www.linux.com/what-is-linux } \\
\text { https://developer.apple.com/discover/ } \\
\text { https://developer.android.com/about }\end{array}$ \\
\hline
\end{tabular}

\section{3. “About Us” Webpages}

Breeze states that "company websites almost always include an 'About Us' section explaining salient aspects of the company's activities [66, p. 147]”. Nodoushan in 2015 conducted a research on 'About Us' pages to find out if these are a distinct genre. He states that "the most effective way of managing an e-business nowadays is by using a suitable webpage. Companies use their 'About Us' pages to introduce themselves [67, p. 69]". It's the page where "you will find everything [...] that you might need or want to know about [a company] [67, p. 70]".

The 'About Us' pages have totally different structures, length, language and depth in information. Nevertheless, they all offer information written by the companies about their value propositions, their assets, their goals and unique selling proposals, which makes them a suitable source for the search for evidence of platform components.

Staying true to the proverb "exceptions confirm the rule", there are three exceptions to the above mentioned. In the case of Angellist, Fortnite and Snap Games, no 'About Us'-page as such was found. Therefore, alternative pages where employed to gather information on the platform.

\subsection{Evaluation Results}

The results show that evidence can be found for the introduced 
components and the four perspectives. From the platform owner's perspective, the components owner, job, transactions, promotion channels, key resources, key activities and governance are validated. From the consumer's perspective, the components consumer, job, pain, gain, filter, transaction, access channel and key activities are supported. From the provider's perspective, the components provider, job, pain, gain, filter, transaction, access channels and key activities are verified. From the partners perspective, the components partner and transaction are confirmed. In addition, the core component 'core value unit' and the two indicative components 'labeling as a platform' and 'vast amount of members' that hint at network effects and underline the existence of a platform-ecosystem are also supported.

The four perspectives (owner, provider, consumer, partner) are unequally often mentioned by the website owners. Although the specific amount of words assigned to each category are not of central interest to this research, it helps to understand that when designing the About-Us-Webpage for a platform business model the four perspectives should deliberately be attended to. This doesn't mean every category has to be mentioned, but it helps to have a systematic approach in the field of online communication strategies. Nevertheless, the amount of words should not be overly stressed as in this research they are to be seen rather as qualitative indicators than as absolute quantitative numbers.

No evidence is found on the 'About Us' pages for the categories pain (owner), gain (owner), key resources (consumer), key resources (provider), job (partner), pain (partner), gain (partner), filter (partner), channel (partner), key resources (partner) and key activities (partner). This does not mean that these components do not exist. Rather it can be argued that because a website is a "communication tool targeted at the end consumer [...] [68, p. 19] "some types of information are mentioned and some are not. Websites are a communication tool and therefore focus on "strategically highlight [ing] the key consumer benefit [s] [69, p. 256]".

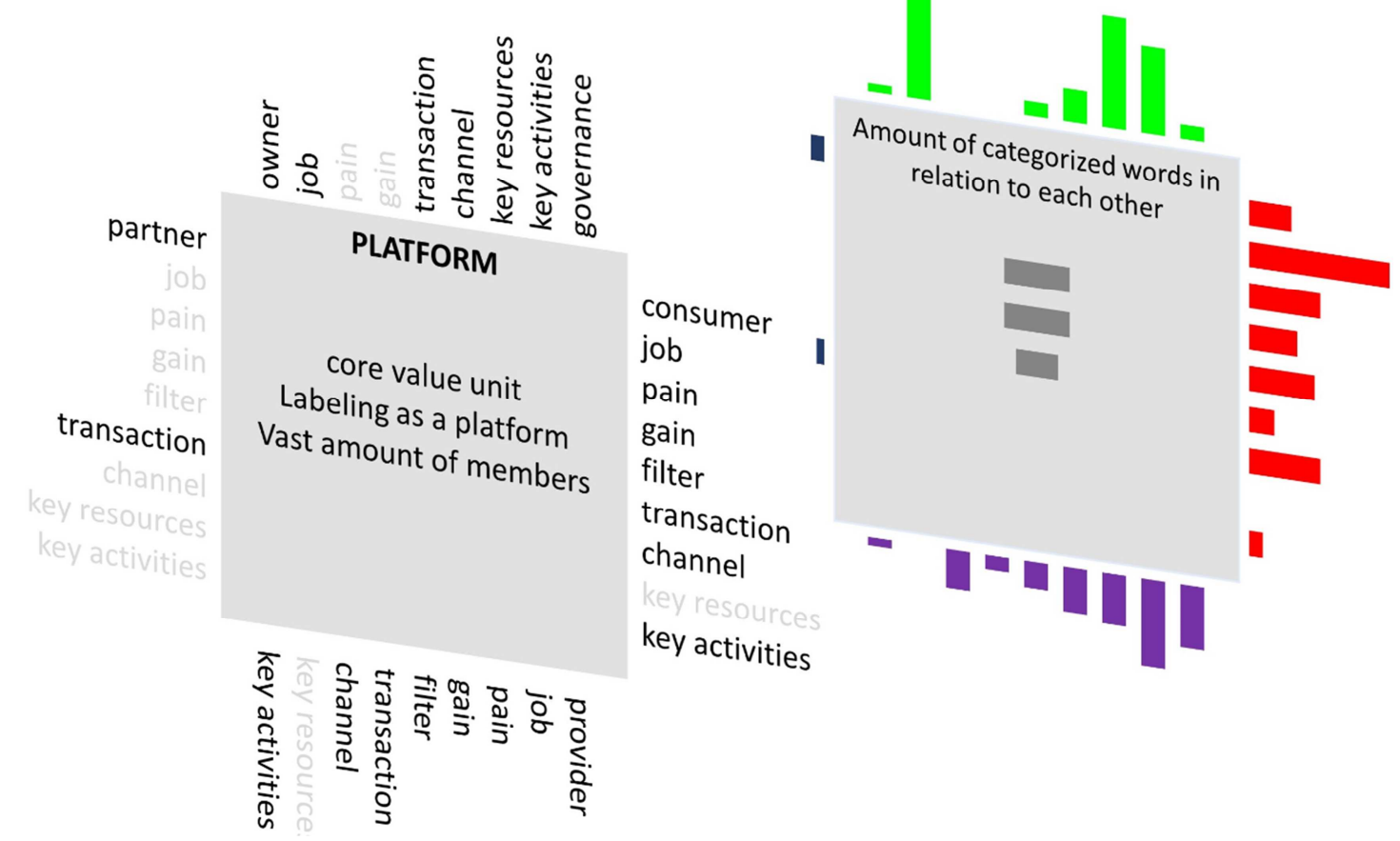

Figure 3. "About Us"-pages of platform websites show evidence of platform components and the four perspectives- own illustration - 'green' stands for the owner perspective, 'red'stands for the consumer perspective, 'purple'stands for the provider perspective, 'blue'stands for the partner perspective and 'grey' stands for the core value unit as well as for the two further indicators.

\section{Introducing the Platform Business Model Canvas (PBMC)}

The building blocks are assembled in a triangular pyramidlike arrangement with respect to the perspectives. The top of the pyramid is central to a platform, and all the components below carry and support the respective components above it.

The participant-pyramids (consumer, provider, partner), described from the top to the bottom, consists of the components job, pain, gain, transaction, which encompasses cost and revenue, resources, activities, channel and filter. Job, the demand or the need for something, is the top of the pyramid, supported by gain that describes the motivation for a demand or a need, and pain that describes challenges and barriers associated to the demand or the need being met. After a demand or a need is being met, the exchange of assets in form of costs or revenue constitute transactions. The prerequisites for successful transactions are the use of key resources, effective key activities, the ideal access channel to the platform for each participant and increasing the matching of the right complementary participants through filters, by helping to sift out innovation and transaction inhibiting participants.

The pyramid of the platform owner consists of the building blocks job, pain, gain, transaction, which encompasses cost 
and revenue, resources, activities, channel and governance, whereas the components have a slightly different meaning compared to the same components of participant's pyramid. Since the focus of the owner is to run and manage the platform job pain and gain can be understood almost as a mission statement for the platform, where the goal is always to match peoples interests in a certain area of service, information or innovation. As a platform owner is interested in capturing value through successful matches and transactions therefrom, understanding cost structure and revenue streams is vital. The last four components help design the framework of the platform. Key resources and activities help keep the platform running. The channel makes the platform available to participants and governance summarizes mechanisms and rules that help keep the platform healthy and prosperous.

When designing or describing a platform, which is always the description of a one- or multi-sided market, a minimum of three pyramids, the owner, the supplying participant and the demanding participant, are necessary. Of course, roles can be overlapping and interchanging, but each role type is described through a respective pyramid. When a platform does not only have owner, suppliers and demanders, but also a partner that through the contribution of key know-how, technology, processes or information is critical to the platform, is also represented through a participant pyramid.

To create a canvas that aggregates all four perspectives the four triangles are aligned on their isosceles sides, whereby the triangular apexes are inside-lying, connecting to each other. The four triangles create a four-sided 3D-pyramid that is then supplemented by the so-called core value unit of the platform at the top. When designing or describing a platform the core value unit is key to every perspective. This value unit must directly correspond to the demand and need every stakeholder has.

The model also helps describe and understand an internal and an external view. The owner and the partner are part of the internal perspectives, as they are key to the backend of the platform. The external view is what the users can 'see' from the platform, basically the frontend.

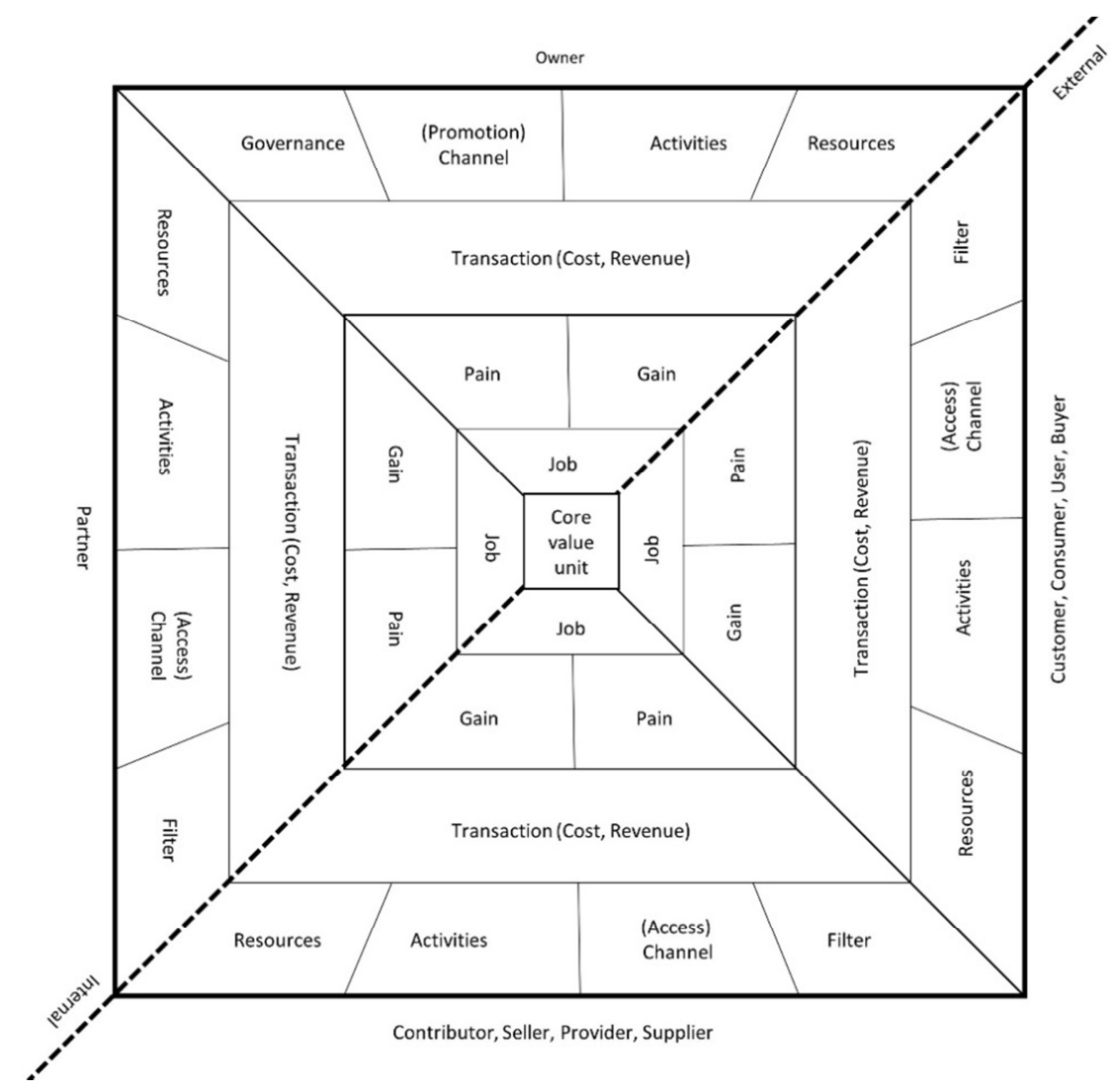

Figure 4. The platform business model canvas - own illustration.

\section{Evaluating the Model}

\subsection{The Illustrative Case Study Method}

Testing and evaluating the adequacy of the building blocks, the model and its instantiation (the canvas) will be accomplished by employing them to describe an existing platform business model in form of an illustrative case studies.
Jahn describes that the illustrative case study is appropriate to illustrate previously identified basic patterns, such as a model [70]. Although this research has identified 10 different types of platform business models, Gawer argues that "at the level of architecture all platform systems are fundamentally the same [71, p. 26].", calling for a universal approach. Therefore, one illustrative case study is conducted explaining the platform business model of eBay, thus underlining 
Gawer's argument.

\subsection{Approach and Results}

The approach is to define questions that directly correspond to the components/building blocks of the platform business model canvas. Therefore, the questions are derived from the platform business model canvas component definitions. Answering the questions is then done by using eBay's websites as well as already existing case studies addressing eBay's platform business model from literature as sources of information (see table 5).

Table 5. Questions and answers to fill the cells of the platform business model canvas for the illustrative case study on eBay.

\begin{tabular}{|c|c|}
\hline Component: & Consumer \\
\hline Question: & Who are key users, buyers, consumers? \\
\hline Answer: & Key buyers at eBay are registered users and unregistered "guests". [72] \\
\hline Component: & Job for consumer \\
\hline Question: & What job can a user, consumer, buyer get done? What need of the consumer, user, buyer can be met? \\
\hline Answer: & eBay facilitates the online buying process in a very easy and user friendly way. $[73$, p. 128$]$ \\
\hline Component: & Pain for consumer \\
\hline Answer: & $\begin{array}{l}\text { Potential fraud is a pain that buyers have, when they buy something and possibly don't get what they paid for. As Lin et al state "[b] uyer } \\
\text { protection is important to its community because the confidence and trust that buyers have in transacting on eBay fuel the whole marketplace. } \\
{[73, \text { p. 129]" eBay eliminates this pain with the so called "eBay Money Back Guarantee" The purchases are covered by the eBay Money }} \\
\text { Back Guarantee for the purchase price and original shipping if buyers don't receive their items or if they are not as described. [74] }\end{array}$ \\
\hline Component: & Gain for consumer \\
\hline Question: & What are positive effects related to the job and need? How can the platform enhance these positive effects? \\
\hline Component: & Filter for consumer \\
\hline Question: & $\begin{array}{l}\text { What are possible access barriers? How can we eliminate them? Who are potential users, buyers, consumers that we don't want on the } \\
\text { platform? How can we ensure that they don't get access to the platform? }\end{array}$ \\
\hline Answer: & $\begin{array}{l}\text { "As an e-commerce business, eBay seeks to provide availability } 24 \text { hs a day, seven days a week [73, p. 128]”. Therefore, eBay aims at } \\
\text { removing possible access barriers for a worldwide usability of the platform through a } 24 \text { hour a day accessibility. }\end{array}$ \\
\hline Component: & Transaction for consumer \\
\hline Question: & $\begin{array}{l}\text { To whom and how does a user, consumer, buyer make a transaction? From whom and how does a user, consumer, buyer receive a } \\
\text { transaction? }\end{array}$ \\
\hline Answer: & The buyer can buy items and then has to make a payment transaction to the seller. [75] \\
\hline Component: & Channel for consumer \\
\hline Question: & Through which channels is the platform accessible for a buyer, user, consumer? \\
\hline Answer: & $\begin{array}{l}\text { "[The] eBay platform helps users access eBay auction services on its web page easily via its ever expanding software tools and services. } \\
\text { [73, p. 129]” (Apps and web) }\end{array}$ \\
\hline Answer: & $\begin{array}{l}\text { Key resources are registration data (user name, user email address and a password) that users need in order to get access to the platform. } \\
\text { [76] At some point, when making a transaction payment data are also needed. }\end{array}$ \\
\hline Component: & Key activities for consumer \\
\hline Question: & What are key activities that users perform on a platform to finish job or meet need? \\
\hline Answer: & Searching and buying are the key activities a buyer can do on the platform. [77] \\
\hline Component: & Provider \\
\hline Question: & Who are key sellers, implementers, providers, contributors, merchants? \\
\hline Answer: & Private people and businesses [78] are the key sellers on the eBay platform. \\
\hline Component: & Job for provider \\
\hline Question: & $\begin{array}{l}\text { What job can sellers, implementers, providers, contributors, merchants get done? What need of sellers, implementers, providers, } \\
\text { contributors, merchants can be met? }\end{array}$ \\
\hline Answer: & $\begin{array}{l}\text { Sellers can basically sell anything on the platform. "Whether you want to make some extra cash, clear out some unwanted items from } \\
\text { around the house, or even start a business, it's easy to start selling on eBay. [79]" }\end{array}$ \\
\hline Component: & Pain for provider \\
\hline Question: & $\begin{array}{l}\text { What are dangers, problems and barriers related to the job done or the need met? How can the platform help reduce, eliminate or solve } \\
\text { these? }\end{array}$ \\
\hline Answer: & $\begin{array}{l}\text { "For the online auction industry, fostering trust and safety within its community is very important. Most people are inherently } \\
\text { uncomfortable with a new way of commerce. In order to make buyers and sellers feel more secure with the transactions they are involved } \\
\text { in, eBay came up with an ingenious way of allowing buyers and sellers to give each other feedback ratings. This feedback forum keeps a } \\
\text { record of the reputation of both sellers and buyers in eBay's community. This information allows users to check and review the integrity of } \\
\text { the other party they are dealing business with; thus, increases trust and buyer/seller confidence before making a purchase [73, p. 129]". } \\
\text { As the platform becomes more successful and the more the number of sellers and items grow, it becomes harder for sellers to be found }\end{array}$ \\
\hline
\end{tabular}


and sell their goods. eBay addresses that pain by offering a promoted listing that helps the sellers items stand out among the other listings on eBay. Of Course, this is not a free offer by eBay, but sellers only pay when an item is actually sold. [80]

Component: Gain for provider

Question: What are positive effects related to the job and need? How can the platform enhance these positive effects?

A gain is to connect sellers with a vast number of potential buyers. "170 million buyers - We're one of the world's largest marketplaces,

Answer: $\quad$ connecting you with buyers near and far [81]”. This can be enhanced by sharing knowledge on how big the buyers network is and by using testimonials to explain the benefits to potential sellers. [82]

Component: Filter for provider

Question: $\quad$ What are possible access barriers? How can we eliminate them? Who are potential seller, implementer, provider, contributor, merchants that we don't want on the platform? How can we ensure that they don't get access to the platform?

In order to reach as many sellers as possible, eBay seeks to provide availability 365 days a year, 24 hours a day. [73]

"For the online auction industry, fostering trust and safety within its community is very important. Most people are inherently uncomfortable with a new way of commerce. In order to make buyers and sellers feel more secure with the transactions they are involved in, eBay came up with an ingenious way of allowing buyers and sellers to give each other feedback ratings. This feedback forum keeps a

Answer: $\quad$ record of the reputation of both sellers and buyers in eBay's community. This information allows users to check and review the integrity of the other party they are dealing business with; thus, increases trust and buyer/seller confidence before making a purchase [73, p. 129]”. In order to maintain the safety of the eBay community, sellers are not allowed to sell certain items that might be harmful to the community. eBay has enlisted these on its website so that sellers know what they can sell. In addition to that users have the possibility to report items that violate eBays policies. [83]

Component: Transaction for provider

Question: $\quad$ To whom and how does a user, consumer, buyer make a transaction? From whom and how does a user, consumer, buyer receive a transaction?

Answer: $\quad$ Sellers have to pay an insertion fee when they create a listing, and a final value fee when their item is sold. [84]

Component: Channel for provider

Question: Through which channels is the platform accessible for sellers, implementers, providers, contributors, merchants?

Answer:

"[The] eBay platform helps users access eBay auction services on its web page easily via its ever expanding software tools and services [73, p. 129]".

Component: Key resources for provider

Question: What are key resources, data, knowhow, expertise, technology that users must invest, to be able to use the platform?

Answer:

Key resources are product data, registration data, and financial resources for fees and listing payments that sellers need to make in order to get access to the platform. [84]

Component:

Question:

Key activities for provider

Answer:

Component:

What are key activities a seller, implementer, provider, contributor, merchants must perform on platform to successfully participate?

Sellers have to describe what they are selling, choose between an auction or a fixed price format, set a price, select their shipping preferences, the return policy and how they want to get paid. [85]

Question:

Answer: Partner

Component:

Who are key partners to keep the platform running and thriving?

Question:

A key partner is PayPal. [86]

Job for partner

What job can partners get done? What need of partners can be met?

PayPal offers its customers the opportunity to pay free of charge via the Internet. PayPal is a very important partner of eBay that was

Answer: bought by eBay in 2002. In order to have a superior user experience eBay introduced an "[...] efficient payment method, which speeded up the settlement of eBay transactions [...] [86, p. 5024]". PayPal, which is a platform on its own, can therefore offer its value proposition on eBay. [86]

Component: $\quad$ Pain for partner

Question: $\quad$ What are dangers, problems and barriers related to the job done or the need met. How can the platform help reduce, eliminate or solve these?

PayPal is the partner of eBay and therefore has access to a vast number of customers. The platform owner might want to offer access to other similar partners in order to create competition on the platform, which in some cases could be beneficial for the sellers and buyers. eBay reduced that pain by acquiring PayPal in 2002 [86] and promoting payments made through PayPal by making it the only payment

Answer: services recognized by eBay's buyer and seller protection plans. Nevertheless, eBay split with PayPal in 2015 and in 2018 announced to replace the partner with another partner (Adyen) until 2020. [87] Another pain is the danger of a so called "Identity Theft", "[...] which involves a fraudster who is neither the payer nor the payee but a third party who steals confidential information from PayPal account holders and uses the funds in their PayPal accounts [73, p. 132]". The platform can try to step up safety measures, so that a hacking of the partner's system through the platform is less possible.

Component: Gain for partner

Question: What are positive effects related to the job and need? How can the platform enhance these positive effects?

The gain for the partner is the access to all other platform stakeholders, which potentially boosts the business for the partner, when the

Answer: $\quad$ platform is successful. eBay boosted that positive effect by making PayPal the only payment services recognized by eBay's buyer and seller protection plans. [88]

Component: Filter for partner

Question:

What are possible access barriers? How can we eliminate them? Who are potential partners that we don't want on the platform? How can we ensure that they don't get access to the platform?

Answer: In the case of eBay partners are given access to the platform through contracts between the owner and the partner. Therefore, unwanted partners don't get access to the platform. Possible access barriers might be downtimes due to processing overload, in case of an ever 
increasing number of users or a malfunctioning or ineffective interfaces between the systems, which constantly need to be updated. [73]

Component:

Question:

Answer:

Component:

Question:

Answer:

Component

Question:

Answer:

Component:

Question:

Answer:

Component:

Question:

Answer:

Component:

Question:

Answer:

Component:

Question:

Answer:

Component:

Question:

Answer:

Component:

Question:

Answer:

Component:

Question:

Answer:

Component:

Question:

Answer:

Component:

Question:

Answer:

Component:

Question:

Answer:

Component:

Question:
Transaction for partne

To whom and how do partners make a transaction? From whom and how do partners receive a transaction?

PayPal receives a transaction fee $(2.9 \%+\$ 0.30$ per sale) from the seller with regards to every item being sold. [89]

Channel for partner

Through which channels is the platform accessible?

From the perspective of PayPal, the platform is accessible through the embedding of its application on the eBay platform. Basically, Application Protocol Interfaces (APIs) are PayPal's channel to access the platform. [73]

Key resources for partner

What are key resources, data, knowhow, expertise, technology that partners must invest, to be able to use the platform?

Developers and cyber security experts are the key human resources PayPal needs to be able to successfully implement their service on the platform. [73]

Key activities for partner

What are key activities that partners perform on a platform to finish a job or meet need?

PayPal is rather passive on the platform, as it makes available its service and then basically tries to incentify the usage through offers like its purchase protection. [74]

Of course, constant updating of the backend and the frontend are key activities. [73]

Owner

Who is the platform owner and who runs the platform?

eBay Inc is the owner of the platform. [81]

Job for owner

what are tasks that the platform owner wants to get done (This is often related to a mission statement and a value proposition of the platform)?

The core job of eBay is to match sellers and buyers. eBay explains that "eBay is where the world goes to shop, sell, and give [81]".

"Whether you are buying new or used, plain or luxurious, commonplace or rare, trendy or one-of-a-kind-if it exists in the world, it probably is for sale on eBay [81]". Lin et al. state that "the role of this platform is to support the company in creating, maintaining and expanding the functionalities of the services and safety for users in this community [73, p. 129]".

Pain for owner

What are dangers, problems and barriers related to the job done or the need met. How can these be reduced, eliminated or solved? "In a competitive space that is "characterized by rapidly changing technology, evolving industry standards, frequent new service and product announcements, introductions and enhancements and changing customer demands," it is essential for eBay to be well-adaptive to its rapidly changing environment and to provide reliable and trustworthy services. In order to ensure a successful business and keep up with its growth, eBay must address challenges such as creating reliable and scalable system architecture, managing a growing contract database and assets, and developing innovative features and enhancements [73, p. 128]".

Gain for owner

What are positive effects related to the job and need? How can these be enhanced?

Positive effects are the so-called network effects that need to be enhanced. "EBay constitutes a good example of a two-sided platform, gathering two types of users - buyers and sellers - with a business model relying on internalizing positive inter-group externalities [90, $\mathrm{p}$. 3] ". "For example, as more people auction items on eBay, buyers gain more valuable service (through reduced search costs), as do sellers (more buyers to purchase products) [91, p. 45]”.

Transaction for owner

To whom and how does the owner make a transaction? From whom and how does the owner receive a transaction? Which transaction fees pay the owner? How are they implemented?

Sellers have to pay an insertion fee when they create a listing, and a final value fee when their item is sold. [84]

Channels for promotion by the owner

Which channels does the owner use to promote the platform?

The platform is being promoted through the own website, through advertising and by helping sellers to promote the things they sell through promotion tools such as the promoted listing [80]. Another approach is to engage the corporate sellers who then use eBay as their online shop, thus increasing the reach of the platform. [92]

Key resources for owner

What are key resources, data, knowhow, expertise, technology that the owner must invest, to keep the platform running and thriving? Financial resources for tool investments, as well as developers and cyber security experts are the key resources eBay needs to be able to successfully grow and protect the platform. compare [93]

Key activities for owner

What are key activities that the owner must do, to keep the platform running and thriving?

"Continuous software and service development is crucial to the future success of eBay [73, p. 129]". "The key activities within eBay.com's value chain architecture are advertising, platform development, registration process, transaction and payment process, communication process, and customer support [93]“.

Governance by owner

What are rules and processes that ensure a high quality of usage and results on the platform and protect these?

The feedback forum is a key governance tool to keep the platform "healthy". [73] The list of forbidden items is another measure to keep the platform "healthy". [83]

Core value unit

What is the core element of the platform to which users and providers align their interests? 


\begin{tabular}{ll}
\hline Answer: & The core value unit of eBay is the listing of an item (which is, the image, the description, the sales mode and the price tag). “A marketplace \\
& like eBay has no value without the product listings on the marketplace. These listings are required to power interactions [94]”.
\end{tabular}

The following graphic summarizes the result of mapping eBay's platform business model to the platform business model canvas.

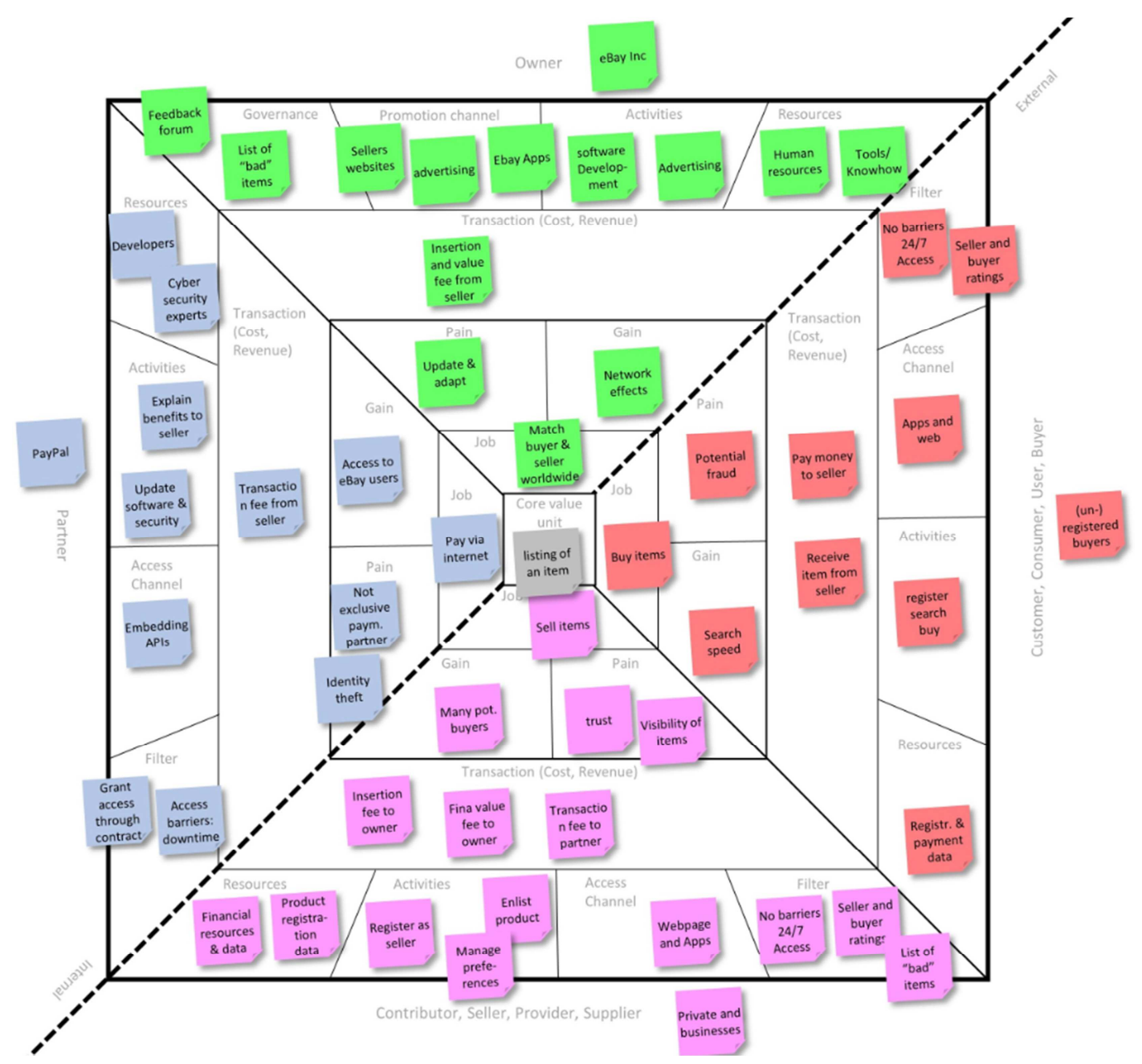

Figure 5. Platform business model canvas for eBay - own illustration.

The order of answering the component-questions does play a role. Concentrating on the components job, pain and gain for each perspective, before then defining the core value unit and then attending the other components helps to create the match of needs and offers right from scratch.

To get an even better result, expert interviews with leading eBay-employees may help to verify the illustrative case study and produce useful feedback on the mapped content and on the eligibility of the platform business model canvas. This case study does not claim to be exhaustive but illustrates a successful instantiation of the platform business model canvas in accordance with the Design Science Framework.

\section{Conclusion}

The goal of this research was to create a platform business model canvas that is easy to use and helps capture platform business models in a comprehensive and effective way.
The constructs, which are the basic components/building blocks as well as the necessary perspectives of the platform business model canvas are derived from literature and furtherly discussed on the basis of Osterwalder's canvas. This is an innovative approach, that will surely spark some discussion.

The constructs were verified through a qualitative analysis of the "About Us"-pages of 31 platform websites. The results are very interesting with regards to website communication approaches and the possible connection of economic impact with certain components being rather prominent and others being subordinate or even unmentioned. The constructs were then put together to a platform business model canvas which was then instantiated through an illustrative case study of eBay's platform business model.

A major area of contribution is the high practical relevance, which enables e.g. managers and business developers to design or describe a platform business model with the 
Platform Business Model Canvas. The tool takes users step by step through the cells and in a very hands-on-approach helps to visualize a platform business model.

Another major area of contribution is the field of academic research. In general, future researches besides describing more platform business models can try to analyze and explain possible links between the economic impact of platforms and their business models with the help of this platform business model canvas. Future research may also alter and adapt this canvas for further applicability in new areas of platform business models, e.g. non-profit platform business.

\section{References}

[1] D. Kindström, 'Towards a service-based business modelKey aspects for future competitive advantage', Eur. Manag. J., vol. 28 , no. 6 , pp. 479-490, 2010.

[2] S. T. March and G. F. Smith, 'Design and natural science research on information technology', Decis. Support Syst., vol. 15, no. 4, pp. 251-266, Dec. 1995.

[3] R. Wieringa, 'Design science as nested problem solving', presented at the Nuclear Instruments \& Methods in Physics Research Section A-accelerators Spectrometers Detectors and Associated Equipment - NUCL INSTRUM METH PHYS RES A, 2009.

[4] M. Stefik, 'The sciences of the artificial: H. A. Simon, second edition (The MIT Press, Cambridge, Massachusetts, 1981); 247 pages, \$4.95', Artif. Intell., vol. 22, no. 1, pp. 95-97, Jan. 1984.

[5] J. F. N. Jr, M. Chen, and T. D. M. Purdin, 'Systems Development in Information Systems Research', J. Manag. Inf. Syst., vol. 7, no. 3, pp. 89-106, Dec. 1990.

[6] P. Palvia and A. F. Salam, 'Management Information Systems Research: What's There in a Methodology?', Commun. Assoc. Inf. Syst., vol. 11, 2003.

[7] P. Palvia, E. Mao, and P. Pinjani, 'Research Methodologies in MIS: An Update', Commun. Assoc. Inf. Syst., vol. 14, 2004.

[8] A. Osterwalder, 'The Business Model Ontology - A Proposition in a Design Science Approach', Jan. 2004.

[9] R. E. Miles, C. C. Snow, A. D. Meyer, and H. J. Coleman, 'Organizational Strategy, Structure, and Process', Acad. Manage. Rev., vol. 3, no. 3, pp. 546-562, Jul. 1978.

[10] G. Q. Huang, T. W. Simpson, and B. J. Pine II, 'The power of product platforms in mass customisation', Int. J. Mass Cust., vol. 1, no. 1, pp. 1-13, 2005.

[11] A. Gawer and M. A. Cusumano, Platform Leadership: How Intel, Microsoft, and Cisco Drive Industry Innovation. Harvard Business School Press, 2002.

[12] T. Eisenmann, G. Parker, and M. W. Van Alstyne, 'Strategies for two-sided markets', Harv. Bus. Rev., vol. 84, no. 10, p. 92, 2006.

[13] A. Gawer and M. A. Cusumano, 'Platform Leaders', MIT Sloan Manag. Rev., 2008.

[14] D. Evans, 'Some Empirical Aspects of Multi-sided Platform
Industries', Rev. Netw. Econ., vol. 2, no. 3, pp. 1-19, 2003.

[15] J.-C. Rochet and J. Tirole, 'Platform Competition in TwoSided Markets', J. Eur. Econ. Assoc., vol. 1, no. 4, pp. 9901029, Jun. 2003.

[16] A. Gawer and M. A. Cusumano, 'Industry Platforms and Ecosystem Innovation: Platforms and Innovation', J. Prod. Innov. Manag., vol. 31, no. 3, pp. 417-433, May 2014.

[17] P. Ritala, V. Agouridas, D. Assimakopoulos, and O. Gies, 'Value creation and capture mechanisms in innovation ecosystems: a comparative case study', Int. J. Technol. Manag., vol. 63, no. 3-4, pp. 244-267, 2013.

[18] R. Adner, B. S. Silverman, and J. E. Oxley, Eds., Collaboration and Competition in Business Ecosystems, vol. 30. Emerald Group Publishing Limited, 2013.

[19] P. C. Evans and A. Gawer, 'The Rise of the Platform Enterprise', p. 30, Jan. 2016.

[20] S. Karanja and B. Arvesen, 'Platform Thinking: Considerations for establishing third-party developer-centric ecosystems', 2018.

[21] S. M. Lee, D. L. Olson, and S. Trimi, 'Co-innovation: convergenomics, collaboration, and co-creation for organizational values', pp. 817-831, 2012.

[22] C. Burmeister, F. T. Piller, and D. Lüttgens, 'Business Model Innovation for Industrie 4.0: Why the Industrial Internet Mandates a New Perspective on Innovation', GBI-Genios Deutsche Wirtschaftsdatenbank GmbH, RWTH-CONV208894, 2016.

[23] D. J. Teece, 'Business Models, Business Strategy and Innovation', Long Range Plann., vol. 43, no. 2, pp. 172-194, Apr. 2010.

[24] P. Kranich, Geschäftsmodellinnovation in der Antriebstechnik: Erfolgreiche Umsetzung in Zeiten der Digitalisierung und Industrie 4.0. Springer-Verlag, 2018.

[25] O. Gassmann, K. Frankenberger, and M. Csik, Geschäftsmodelle entwickeln: 55 innovative Konzepte mit dem St. Galler Business Model Navigator. Carl Hanser Verlag GmbH Co KG, 2017.

[26] E. Fielt, 'Conceptualising business models: Definitions, frameworks and classifications', J. Bus. Models, vol. 1, no. 1, pp. 85-105, 2014.

[27] A. Osterwalder and Y. Pigneur, Business Model Generation: A Handbook for Visionaries, Game Changers, and Challengers. John Wiley \& Sons, 2010.

[28] F. Lüdeke-Freund, 'Business Models for Sustainability Innovation: Conceptual Foundations and the Case of Solar Energy', 2013.

[29] S. M. Shafer, H. J. Smith, and J. C. Linder, 'The power of business models', Bus. Horiz., vol. 48, no. 3, pp. 199-207, May 2005.

[30] R. Amit and C. Zott, 'Value creation in E-business', Strateg. Manag. J., vol. 22, no. 6-7, pp. 493-520, 2001.

[31] K. Storbacka, C. Windahl, S. Nenonen, and A. Salonen, 'Solution business models: Transformation along four continua', Ind. Mark. Manag., vol. 42, no. 5, pp. 705-716, 2013. 
[32] R. Casadesus-Masanell and J. E. Ricart, 'From Strategy to Business Models and onto Tactics', Long Range Plann., vol. 43, no. 2, pp. 195-215, Apr. 2010.

[33] S. Cavalcante, P. Kesting, and J. P. Ulhøi, 'Business Model Dynamics and Innovation: (Re) establishing the Missing Linkages', Social Science Research Network, Rochester, NY, SSRN Scholarly Paper ID 1991809, 2011.

[34] C. Zott and R. Amit, 'Business Model Design and the Performance of Entrepreneurial Firms', Organ. Sci., vol. 18, no. 2, pp. 181-199, Apr. 2007.

[35] B. Demil and X. Lecocq, 'Business Model Evolution: In Search of Dynamic Consistency', Long Range Plann., vol. 43, no. 2, pp. 227-246, Apr. 2010.

[36] G. George and A. J. Bock, 'The Business Model in Practice and its Implications for Entrepreneurship Research', Entrep. Theory Pract., vol. 35, no. 1, pp. 83-111, 2011.

[37] T. Palo and J. Tähtinen, 'Networked business model development for emerging technology-based services', Ind. Mark. Manag., vol. 42, no. 5, pp. 773-782, 2013.

[38] S. Svejenova, M. Planellas, and L. Vives, 'An individual business model in the making: A chef's quest for creative freedom', Long Range Plann., vol. 43, no. 2-3, pp. 408-430, 2010 .

[39] M. M. Al-Debei, R. El-Haddadeh, and D. Avison, 'Defining the business model in the new world of digital business', AMCIS 2008 Proc., p. 300, 2008.

[40] C. Zott and R. Amit, 'Business model design: an activity system perspective', Long Range Plann., vol. 43, no. 2-3, pp. 216-226, 2010.

[41] M. W. Johnson, C. M. Christensen, and H. Kagermann, 'Reinventing Your Business Model', Harvard Business Review, no. December 2008, 01-Dec-2008.

[42] W. K. Smith, A. Binns, and M. L. Tushman, 'Complex business models: Managing strategic paradoxes simultaneously', Long Range Plann., vol. 43, no. 2-3, pp. 448-461, 2010.

[43] C.-C. Yu, 'An integrated framework of business models for guiding electronic commerce applications and case studies', in International Conference on Electronic Commerce and Web Technologies, 2001, pp. 111-120.

[44] J. Wareham, P. B. Fox, and J. L. Cano Giner, 'Technology ecosystem governance', Organ. Sci., vol. 25, no. 4, pp. 11951215,2014

[45] P. Timmers, 'Business models for electronic markets', Electron. Mark., vol. 8, no. 2, pp. 3-8, 1998.

[46] P. Weill and M. Vitale, Place to space: Migrating to eBusiness Models. Harvard Business Press, 2001.

[47] T. Kohler, 'Crowdsourcing-based business models: how to create and capture value', Calif. Manage. Rev., vol. 57, no. 4, pp. 63-84, 2015.

[48] A. Osterwalder, Y. Pigneur, G. Bernarda, and A. Smith, Value proposition design: How to create products and services customers want. John Wiley \& Sons, 2014.

[49] G. Parker, M. W. van Alstyne, and S. P. Choudary, Platform
Revolution: How Networked Markets are Transforming the Economy--and How to Make Them Work for You. New York: Norton \& Company, 2016.

[50] J. Sanderse, 'The business model canvas of NGOs', Master's Thesis, Open Universiteit Nederland, 2014.

[51] M. Schreieck, M. Wiesche, and H. Krcmar, 'Design and Governance of Platform Ecosystems-Key Concepts and Issues for Future Research.', in ECIS, 2016, p. Research Paper 76.

[52] Dr. S. von Engelhardt, Dr. L. Wangler, and Dr. S. Wischmann, 'Eigenschaften und Erfolgsfaktoren digitaler Plattformen'. Begleitforschung AUTONOMIK für Industrie 4.0 iit-Institut für Innovation und Technik in der VDI/VDE Innovation + Technik GmbH, Alfons Botthof, Mar-2017.

[53] M. Walter, 'Endlich ein Canvas für PlattformGeschäftsmodelle', deutsche-startups. de, 05-Apr-2016.

[54] N. Walton, 'Ecosystems Thinking and Modern PlatformBased Ecosystem Theory', in The Internet as a TechnologyBased Ecosystem, Springer, 2017, pp. 85-117.

[55] J. Sydow, Strategische Netzwerke: evolution und organisation. Springer-Verlag, 2013.

[56] L. Feist, An Introduction to Popular Music Publishing in America. National Music Publisher's Association, 1980.

[57] H. W. Chesbrough, Open Innovation: The New Imperative for Creating and Profiting from Technology. Harvard Business Press, 2006.

[58] K. Sornum, Creative Commons. GRIN Verlag, 2010.

[59] K. Crabb, The Movie Business: The Definitive Guide to the Legal and Financial Secrets of Getting Your Movie Made. Simon and Schuster, 2005.

[60] P. Mayring, 'Qualitative Content Analysis', Forum Qual. Sozialforschung Forum Qual. Soc. Res., vol. 1, no. 2, Jun. 2000.

[61] Provalis, 'Qualitative Data Analysis Software, Mixed Methods Research Tool | Provalis', Provalis Research, 05May-2019. [Online]. Available: https://provalisresearch.com/products/qualitative-dataanalysis-software/. [Accessed: 05-May-2019].

[62] S. B. Letaifa, A. Gratacap, and T. Isckia, Understanding Business Ecosystems: How Firms Succeed in the New World of Convergence? De Boeck Superieur, 2013.

[63] 'Platform Types: What they are and how to design platforms by type', Applico, 20-Oct-2017. [Online]. Available: https://www.applicoinc.com/blog/what-makes-uber-differentfrom-android-how-to-make-sense-of-platform-businesses/. [Accessed: 05-May-2019].

[64] C. Linz, A. Zimmermann, and G. Müller-Stewens, Radical Business Model Transformation: Gaining the Competitive Edge in a Disruptive World. Kogan Page Publishers, 2017.

[65] Brand Finance, 'Brand Finance US 500 2019.pdf'. Brand Finance, Mar-2019.

[66] R. Breeze, Corporate Discourse. A \& amp; C Black, 2013.

[67] M. A. S. Nodoushan, International Journal of Language Studies (IJLS) - volume 9 (2). Lulu.com, 2015. 
[68] P. de Pelsmacker, M. Geuens, and J. van den Bergh, Foundations of Marketing Communications: A European Perspective. Pearson Education, 2005.

[69] R. Blakeman, Integrated Marketing Communication: Creative Strategy from Idea to Implementation. Rowman \& Littlefield, 2014.

[70] D. Jahn, Einführung in die vergleichende Politikwissenschaft. Springer-Verlag, 2011.

[71] A. Gawer, Platforms, Markets and Innovation. Edward Elgar Publishing, 2011.

[72] C. S. eBay, 'Buying | eBay', eBay Customer Service/Buying, Jul-2019. [Online]. Available: https://www.ebay.com/help/buying. [Accessed: 07-Jul-2019].

[73] L. H. Lin, A. Tanyavutti, and S. Jindrapacha, 'Analyzing eBay Platform Strategies: An Application of Meyer's Product Platform Strategy Model', in PICMET '07 - 2007 Portland International Conference on Management of Engineering Technology, 2007, pp. 125-142.

[74] purchase protection eBay, 'eBay: PayPal: PayPal and purchase protection on eBay', eBay purchase protection, Jul2019. [Online]. Available: https://pages.ebay.com/kh/enus/paypal/buyer/. [Accessed: 07-Jul-2019].

[75] C. S. eBay, 'How buying works', eBay - How buying works, Jul-2019. [Online]. Available: https://www.ebay.com/help/buying/buy-now/buyingworks?id=4002. [Accessed: 07-Jul-2019].

[76] C. S. eBay, 'Signing up for an eBay account', eBay - Signing up for an eBay account, Jul-2019. [Online]. Available: https://www.ebay.com/help/account/account-gettingstarted/setup-verify?id=4191. [Accessed: 07-Jul-2019].

[77] finding items eBay, 'Finding items', eBay findingitems, Jul2019. [Online]. Available: https://www.ebay.ca/pages/help/search/findingitems.html. [Accessed: 07-Jul-2019].

[78] V. eBay, 'eBay Verkäuferportal', eBay Verkäuferprotal, Jul2019. [Online]. Available: https://verkaeuferportal.ebay.de/. [Accessed: 07-Jul-2019].

[79] C. S. eBay, 'Selling | eBay', eBay Customer Service, Jul-2019. [Online]. Available: https://www.ebay.com/help/selling. [Accessed: 07-Jul-2019].

[80] S. C. eBay, 'Promoted Listings', eBay Seller Center, Jul-2019. [Online]. Available: http://pages.ebay.com/sellercenter/listing-and-marketing/promoted-listings.html. [Accessed: 07-Jul-2019].

[81] W. W. A. eBay, 'Who We Are - eBay Inc.', our company ebay Inc, 07-Jul-2019. [Online]. Available: https://www.ebayinc.com/our-company/who-we-are/. [Accessed: 07-Jul-2019].

[82] S. C. eBay, 'Sell Around the World', eBay Seller Center, Jul-
2019. [Online]. Available: http://pages.ebay.com/sellercenter/shipping/selling-internationally.html. [Accessed: 07Jul-2019].

[83] C. S. eBay, 'Prohibited and restricted items', eBay Prohibited and restricted items, Jul-2019. [Online]. Available: https:/www.ebay.com/help/policies/prohibited-restricteditems/prohibited-restricted-items?id=4207. [Accessed: 07-Jul2019].

[84] C. S. eBay, 'Selling fees', eBay - Selling fees, Jul-2019. [Online]. Available: https://www.ebay.com/help/selling/feescredits-invoices/selling-fees?id=4364. [Accessed: 07-Jul2019].

[85] C. S. eBay, 'Creating a listing', eBay - creating a listing, Jul$2019 . \quad$ [Online]. Available: https://www.ebay.com/help/listings/creating-managinglistings/creating-listing?id=4105. [Accessed: 07-Jul-2019].

[86] K. Staykova and J. Damsgaard, 'Introducing Platform Interactions Model for Studying Multi-Sided Platforms', 2018.

[87] P. R. eBay, 'eBay wird die Zahlungsabwicklung auf seiner Marktplatz-Plattform übernehmen - eBay Inc.', eBay wird die Zahlungsabwicklung auf seiner Marktplatz-Plattform übernehmen, 01-Feb-2018. [Online]. Available: https://www.ebayinc.com/stories/press-room/de/ebay-wirddie-zahlungsabwicklung-auf-seiner-marktplatz-plattformuebernehmen/. [Accessed: 07-Jul-2019].

[88] S. and S. PayPal, 'PayPal Purchase Protection for Buyers PayPal US', Jul-2019. [Online]. Available: https://www.paypal.com/us/webapps/mpp/paypal-safety-andsecurity. [Accessed: 07-Jul-2019].

[89] F. PayPal, 'Credit Card Fees, Send Money Fees \& Other Charges - PayPal US', PayPal fees are always fair, Jul-2019. [Online]. https://www.paypal.com/us/webapps/mpp/paypal-fees. [Accessed: 07-Jul-2019].

[90] C. Curchod and N. Neysen, Disentangling positive and negative externalities on two-sided markets: the Ebay Case. Université catholique de Louvain Working Paper, 2009.

[91] G. J. Browne and N. M. Menon, 'Network effects and social dilemmas in technology industries', IEEE Softw., vol. 21, no. 5, pp. 44-50, Sep. 2004.

[92] S. C. eBay, 'New Business Seller', eBay Seller Center, Jul2019. [Online]. Available: http://pages.ebay.com/sellercenter/get-started/new-business-seller.html. [Accessed: 07Jul-2019].

[93] C. Comberg and V. K. Velamuri, 'The introduction of a competing business model: the case of eBay', Int. J. Technol. Manag., vol. 73, no. 1-3, pp. 39-64, 2017.

[94] S. P. Choudary, 'Platform Scale - How an emerging business model helps startups build large empires with minimum investment', Platf. Think. Labs Pte Ltd, no. First Edition, p. $250,2015$. 